() Elsevier/INRA

\title{
In situ evaluation of the ruminal and intestinal degradability of extruded whole lupin seed nitrogen
}

\author{
P Cros, C Benchaar, C Bayourthe, M Vernay *, R Moncoulon \\ ENSAT, Laboratoire de Zootechnie et des Productions Animales, \\ 145, Av de Muret, 31076 Toulouse Cedex, France
}

(Received 2 February 1991; accepted 25 July 1991)

\begin{abstract}
Summary - The effect of whole lupin seeds (Lupinus albus cv Lublanc) at 120,150 and $195^{\circ} \mathrm{C}$ on in situ nitrogen degradability (Dg.N) was measured by the nylon bag technique using fistulated nonlactating Holstein cows. The $\mathrm{N}$ degradation was evaluated in nylon bags suspended in the rumen; heating the seeds at 120,150 and $195^{\circ} \mathrm{C}$ decreased the Dg.N value: 83.9, 72.9 and 53.0 respectively vs $95.3 \%$ (rumen outflow rate of $0.06 / \mathrm{h}$ ). To estimate the total $\mathrm{N}$ disappearing in the digestive tract, bags were incubated in the rumen for $16 \mathrm{~h}$, then in a pepsin bath for $2 \mathrm{~h}$ and then introduced into the duodenum for subsequently recovery in feces. The whole tract degradability of $\mathrm{N}$ was always high, approximately $98.3 \%$. The amounts of $\mathrm{N}$ which disappeared in the intestine increased from 3.1 (untreated seeds) to $15.1,26.3$ and $44.7 \%$ as the temperature rose to 120,150 and $195{ }^{\circ} \mathrm{C}$ respectively. The PDIN and PDIE contents ( $\mathrm{g} / \mathrm{kg}$ of DM) of the raw whole lupin seeds were 224 and 84 respectively; extrusion elevated these values by $10-32 \%$ for PDIN and $57-194 \%$ for PDIE. The augmentation in the supply of dietary proteins to the postruminal parts as a result of extrusion could rapidly benefit high yielding cows.
\end{abstract}

lupin seeds / extrusion / cows / in situ degradability / rumen / intestine

Résumé - Évaluation in situ des dégradabilités ruminale et intestinale des matières azotées des graines de lupin extrudées. Quatre vaches laitières taries, de race Holstein, munies de canules (rumen et duodénum) ont été utilisées afin de déterminer l'effet de l'extrusion à 120, 150 et $195^{\circ} \mathrm{C}$ de la graine de lupin (Lupinus albus cv Lublanc) sur la dégradabilité in situ des matières azotées (MA) dans le rumen et l'intestin. Après traitement à 120,150 et $195^{\circ} \mathrm{C}$, la dégradabilité théorique des MA dans le rumen diminue : 83,6, 89,7, 72,3 et 53,0 respectivement contre $95,1 \%$ (avec un taux de passage théorique des particules de 0,06/h). Des sacs incubés pendant $16 \mathrm{~h}$ dans le rumen ont été introduits dans l'intestin via la canule duodénale et récupérés dans les fèces. La disparition des MA dans l'ensemble du tractus digestif n'est pas modifiée par l'extrusion (98,3\%). En conséquence, la fraction azotée d'origine alimentaire qui disparaît dans les régions postruminales augmente avec la température d'extrusion, soit : 15,1, 15,7, 26,3 et 44,7\% lorsque les graines sont respectivement traitées à 120,150 et $195{ }^{\circ} \mathrm{C}$; la disparition intestinale n'étant que de $3,1 \%$ pour les graines non traitées. Les valeurs de PDI ( $g / \mathrm{kg} M S$ ) estimées pour le lupin cru sont : 224 (PDIN) et 84 (PDIE); l'extrusion augmente ces valeurs, ie, 10 à 32\% (PDIN) et 57 à 194\% (PDIE). La cuissonextrusion protège les MA de la graine de lupin de la digestion bactérienne dans le rumen et accroit l'apport de MA d'origine alimentaire dans l'intestin grêle.

lupin / extrusion / vaches / dégradabilité in sacco / rumen / intestin

\footnotetext{
* Correspondence and reprints
} 


\section{INTRODUCTION}

Large quantities of protein are required by dairy cows to maintain high milk production. This can be enhanced by feeding nondegradable proteins or by protecting supplementary crude protein from excessive breakdown. Attempts have been made to increase the quantity of protein reaching the small intestine of ruminants by heat-treatment (Stern et al, 1985; Thomas et al, 1987; Stutts et al, 1988). Low alkaloid and high protein and lipid contents in sweet white lupin seeds (Cerning-Beroard and Filiatre, 1977) indicate a potential use as a protein supplement in ruminal diets. Unfortunately, poor performances of lactating dairy cows fed lupin seeds have been reported (Guillaume et al, 1987); these could be partly due in a reduced true protein in the small intestine. Until now, little information has been reported concerning the benefit of heating this proteaginous seed to reduce protein breakdown in the rumen (Emile et al, 1988 ) and to increase small intestine availability of rumen undegraded dietary nitrogen $(N)$.

Consequently, the objective of our study was to determine the effect of extrusion at 120,150 and $195^{\circ} \mathrm{C}$ on whole lupin seeds (WLS) by measuring: 1) N solubility in artificial saliva and 2) degradation of $\mathrm{N}$ contents in nylon bags within the rumen and intestine of non-lactating Holstein cows.

\section{MATERIALS AND METHODS}

\section{Animals and diets}

Four non-lactating Holstein cows weighing 600 $\mathrm{kg}$, fitted with ruminal and proximal duodenal cannulas, were used. Animals were housed in individual stalls with free access to both feed and water. Basal diet consisted of $70 \%$ Italian rye-grass hay and $30 \%$ of hammermilled WLS on a dry matter (DM) basis. Animals were given one half of their assigned diet at $9.00 \mathrm{~h}$ and one half at $17.00 \mathrm{~h}$ daily. The mean daily DM intake was $\approx 10 \mathrm{~kg}$.

\section{Protein sources}

The protein sources tested were WLS (Lupinus albus cv Lublanc) raw or extruded ${ }^{*}$ at 120 $\left(E W L S_{120}\right), \quad 150 \quad\left(E W L S_{150}\right)$ and $195{ }^{\circ} \mathrm{C}$ $\left(E W L S_{195}\right)$ and ground finely enough to pass through a 1-mm screen; EWLS were from the same batch as RWLS. Chemical composition of the WLS used for in situ incubations is listed in table I.

\section{In situ incubation of protein sources}

Nylon bags made from Blutex $T_{50}$ (Tripette et Renaud, Paris, France) and having a mean pore size of $46 \mu \mathrm{m}$ were used throughout the study. Five-g samples of milled WLS were placed into $7 \times 11 \mathrm{~cm}$ heat-sealed nylon bags. Sixty-four bags were prepared for each protein source. Twelve bags per feedstuff (RWLS and EWLS) per cow were introduced into the ventral sac of the rumen immediately before the morning feeding and anchored by a nylon cord string to the cap of the ruminal cannula. Two bags were taken out of the rumen after incubation for $2,4,8$, 16,24 and $48 \mathrm{~h}$, briefly rinsed under cold tap water to eliminate surface debris and machinewashed ( $2 \times 5 \mathrm{~min}$ ) to remove rumen fluid; then nylon bags were dried at $60^{\circ} \mathrm{C}$ for $48 \mathrm{~h}$ in a forced air oven.

The total $\mathrm{N}$ disappearing in the digestive tract was obtained by further incubation of 4 bags $(6 \times 6 \mathrm{~cm} ; 1.5 \mathrm{~g})$ per feedstuff per cow. After initial rumen exposure for $16 \mathrm{~h}$ (Michalet-Doreau et al, 1987), the bags were removed, rinsed, incubated at $40^{\circ} \mathrm{C}$ for a further $2 \mathrm{~h}$ with pepsin solution ( $3 \mathrm{~g} / /$ in $0.1 \mathrm{~N} \mathrm{HCl})$, rinsed again and inserted into the small intestine through the

\footnotetext{
* Extruder, Instapro, Dievet, France
} 
Table l. Dry matter (DM) content, composition of the DM and nitrogen (N) solubility of the raw and extruded whole lupin seeds.

EWLS

RWLS $\quad 120^{\circ} \mathrm{C} \quad 150^{\circ} \mathrm{C} \quad 195^{\circ} \mathrm{C}$

$\begin{array}{lrrrr}\text { Dry matter (\% feedstuff) } & 91.8 & 95.4 & 95.6 & 95.8 \\ \text { Composition of DM (\%) } & & & & \\ \text { Protein (N } \times 6.25) & 38.8 & 38.4 & 38.1 & 38.3 \\ \text { Ether extract } & 8.7 & 8.3 & 7.9 & 7.6 \\ \text { Neutral detergent fiber } & 24.0 & 20.8 & 20.8 & 19.5 \\ \text { Acid detergent fiber } & 16.1 & 16.9 & 18.6 & 17.6 \\ \text { Organic matter } & 95.6 & 94.9 & 95.6 & 95.8 \\ \text { N soluble (\% total N) } & 80.5 & 33.2 & 26.9 & 21.8\end{array}$

Whole lupin seeds: raw (RWLS) and extruded (EWLS).

duodenal cannula (Peyraud et al, 1988). Bags recovered from the feces were treated similarly to those removed from the rumen. Bags not recovered within $30 \mathrm{~h}$ were discarded (de Boer et al, 1987).

\section{Biochemical analyses}

Dry matter was determined in feedstuffs $\left(105^{\circ} \mathrm{C}\right.$ overnight). Evaluations of organic matter and fat in WLS were made according to the methods recommended by the AOAC (1984), neutral and acid detergent fiber contents of WLS were estimated by the procedure described by Van Soest (1963) and Van Soest and Wine (1967). Nitrogen (Kjeldahl) was determined both in feedstuffs and in residuals; from this, protein was determined as $\mathrm{N} \times 6.25$. In addition, soluble $\mathrm{N}$ in each protein source (RWLS, EWLS) was determined after extraction in artificial saliva (bicarbonatephosphate buffer; $\mathrm{pH}=6.9$ ) according to the procedure of Vérité and Demarquilly (1978).

\section{Calculations}

Disappearance of DM and $N$ from the nyion bags at each incubation time was calculated from the respective amounts remaining after in- cubation in the rumen. The in situ degradability kinetics for $\mathrm{DM}$ and $\mathrm{N}$ were studied using the exponential model proposed by Ørskov and McDonald (1979) using the Marquardt algorithm for non-linear regression analysis (STATITCF, 1985):

$$
\operatorname{Dg}(t)=a+b\left(1-e^{-c t}\right)
$$

where $D g(t)=$ degradability at time $t, a$ :=the rapidly soluble component; $b=$ the less rapidly degradable component, which disappears at the constant fractional rate $c$, per time $t$. In addition, the degradability $(\mathrm{Dg})$ was estimated according to the equation $\mathrm{Dg}=a+(b c) /(c+k)$, where $a$, $b$ and $c$ are in equation ( 1 ) and $k$ is the estimated rate of solid outflow from the rumen, assumed to be $0.06 / \mathrm{h}$. The amount of digestible $\mathrm{DM}$ and $\mathrm{N}$ reaching the intestine was evaluated as the difference between whole tract digestion and Dg.DM or Dg.N.

The PDI (protein digested in the small intestine) contents of the feedstuffs were evaluated using the Dg.N, the undegraded $\mathrm{N}$ digestibility in the small intestine calculated as: $[(1-D g . N)$ residual rumen undegraded $N] /(1-D g . N)$ and fermentable organic matter data derived from present work and the equations proposed by Vérité et al (1987) and Vérité and Reynaud, 1989). The RWLS and EWLS organic matter digestibilities used were 0.91 and 0.88 respectively (unpublished results). 
Disappearances of DM and $\mathrm{N}$ from bags incubated in the rumen and in the rumen plus intestine were analysed statistically using analysis of variance for feedstuffs or temperature effects within each rumen incubation time. Linear regression and correlation coefficients were used to compare $\mathrm{N}$ disappearance from the bags at each of the rumen exposure time with $\mathrm{N}$ solubility in vitro for all feedstuffs. Results are presented as means with their standard errors. Differences were evaluated statistically using ANOVA, significances being declared at $P<$ 0.05 .

\section{RESULTS}

\section{Nitrogen solubility}

Buffer-soluble-N from RWLS and EWLS sources is presented in table I. Solubility (\%) of the RWLS-N in artificial saliva was high (80.5). Extrusion at 120, 150 and $195^{\circ} \mathrm{C}$ reduced this value by 59,67 and $73 \%$ respectively.

\section{In situ evaluation of the ruminal degradability}

Loss of DM and $\mathrm{N}$ from bags over a 48-h period for each of the WLS studied is given in figure 1. After $2 \mathrm{~h}$ of incubation, the disappearance of DM and $\mathrm{N}$ from the rumen was significantly higher for RWLS than for EWLS. However, with longer incubations, the effect of processing gradually decreased, so that by $48 \mathrm{~h}$, the loss of DM and $\mathrm{N}$ from the treated grains was the same as from the untreated grains. As indicated by data in table II, there were direct linear relationships between the solubility and the disappearance of $\mathrm{N}$. The correlation was influenced by residence time of the bags in the rumen and a significant relationship was only found between
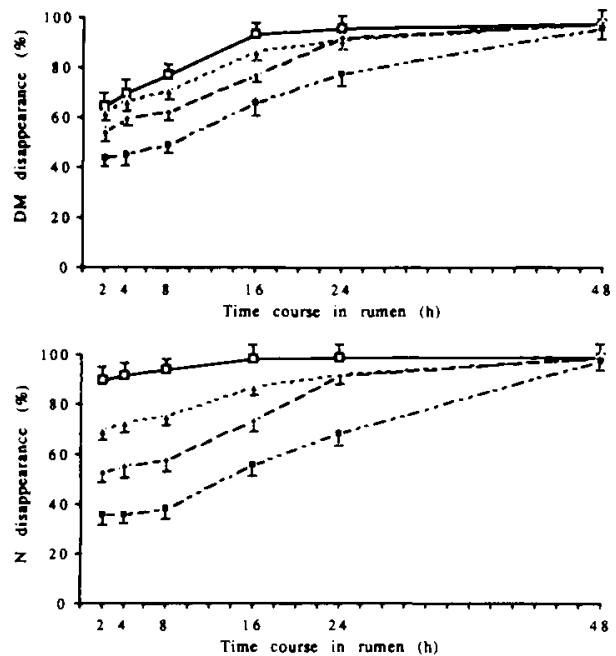

Fig 1. Percentage disappearance of dry matter (DM) and nitrogen (N) of the whole lupin seeds raw (- $\square$ ) and extruded at $120(-\mathbf{A}-), 150$ $(-\bullet)$ and $195^{\circ} \mathrm{C}(--)$, from nylon bags as a function of ruminal incubation time. Each vertical bar indicates the standard error of difference between 8 samples.

Table II. Relationships between in situ degradability of nitrogen $(\mathrm{N})$ and in vitro $\mathrm{N}$ solubility of the whole lupin seeds.

\begin{tabular}{cccc}
\hline $\begin{array}{c}\text { Rumen } \\
\text { exposure } \\
\text { time }(h)\end{array}$ & $\begin{array}{c}\text { Predicted } \\
\text { equations }\end{array}$ & RSE & $r$ \\
& & & \\
\hline & & & \\
2 & $y=31.62+0.74 x$ & 10.63 & $0.91^{*}$ \\
4 & $y=33.70+0.73 x$ & 11.68 & $0.90^{*}$ \\
8 & $y=36.45+0.72 x$ & 11.70 & $0.90^{*}$ \\
16 & $y=56.36+0.54 x$ & 10.36 & $0.87^{*}$ \\
& & & \\
\hline
\end{tabular}

$y=$ mean value of in situ $\mathrm{N}$ degradability $(\%)$ and $x=\mathrm{N}$ solubility (\%). RSD : residual standard deviation; correlation coefficients $(r)$ were evaluated from experiments performed with the raw and extruded whole lupin seeds; " significant relationship. 
$\mathrm{N}$ solubility and $\mathrm{N}$ disappearance from bags at 2, 4, 8 and $16 \mathrm{~h}$ of rumen incubation.

The parameters defining the equations describing the pattern of DM and $\mathrm{N}$ degradation as well as the Dg.DM and Dg.N values are presented in table III. Coefficients of determination $\left(r^{2}\right)$ for disappearance of $\mathrm{DM}$ and $\mathrm{N}$ were significant and the Dg.N values were 82.8 and $95.1 \%$ respectively. Processing the WLS at the indicated levels $\left(120,150,195^{\circ} \mathrm{C}\right)$ was followed by a decrease in the proportion of the rapidly soluble $\mathrm{N}$ fraction (a) and both increased the proportion and reduced the breakdown rate (c) of the fraction (b). Therefore, extrusion of WLS diminished the Dg.DM value by $3.9 \%$ for EWLS $_{120}, 11.1 \%$ for EWLS $_{150}$ and $27.9 \%$ for EWLS 195 ; the corresponding reductions of the Dg.N value were: 12 , 23.7 and $44.3 \%$.

In sacco Dg.N values of WLS (raw and extruded) were significantly correlated with the $\mathrm{N}$ solubility (s); the regression equation was: Dg. $\mathrm{N}=53.9+0.54 s(r=0.82$;
$R S D=12.6)$. In addition, correlations were also found between the coefficient $a$ in situ and the $\mathrm{N}$ solubility (s) in vitro; the corresponding equation was: $a=12.6+0.88 s$ $(r=0.92 ; R S E=12.7)$.

\section{Evaluation of the intestinal disappearance}

Total disappearance of DM and $N$ from bags during transit through the digestive tract in depicted in figure 2. The percentages observed for the whole tract digestion of DM (89.2 - 90.9\%) and N (97.5 $98.7 \%$ ) were always high. Although processing of WLS significantly depressed Dg.DM and Dg.N values, the whole tract disappearance of these components was not significantly affected. Consequently, the amount of DM which disappeared in the postruminal sections increased from 8.1 (RWLS) to $10.6,15.6$ and $26.8 \%$ as the temperature of the extruded grains rose to $\approx 120,150$ and $195^{\circ} \mathrm{C}$ respective-

Table III. Coefficients of degradability kinetics, in sacco degradability and $r^{2}$ values of dry matter and nitrogen of the whole lupin seeds.

\begin{tabular}{|c|c|c|c|c|c|c|}
\hline & & $a$ & $b$ & $c$ & $r^{2}$ & $D g$ \\
\hline \multicolumn{7}{|c|}{ Dry matter } \\
\hline \multirow[t]{2}{*}{ RWLS } & & $43.9 \pm 1.1$ & $53.7 \pm 2.2$ & $16.0 \pm 0.6$ & 0.92 & 82.8 \\
\hline & $120^{\circ} \mathrm{C}$ & $49.4 \pm 1.1$ & $48.1 \pm 2.0$ & $10.1 \pm 0.5$ & 0.83 & 79.6 \\
\hline \multirow{2}{*}{ EWLS } & $150^{\circ} \mathrm{C}$ & $33.1 \pm 2.6$ & $64.3 \pm 2.5$ & $10.2 \pm 0.5$ & 0.86 & 73.6 \\
\hline & $195^{\circ} \mathrm{C}$ & $38.4 \pm 1.2$ & $57.6 \pm 2.0$ & $3.5 \pm 0.6$ & 0.90 & 59.7 \\
\hline \multicolumn{7}{|l|}{ Nitrogen } \\
\hline \multirow[t]{2}{*}{ RWLS } & & $80.7 \pm 0.7$ & $18.3 \pm 0.7$ & $22.1 \pm 0.6$ & 0.96 & 95.1 \\
\hline & $120^{\circ} \mathrm{C}$ & $56.5 \pm 1.7$ & $42.7 \pm 2.9$ & $10.4 \pm 0.9$ & 0.70 & 83.6 \\
\hline \multirow[t]{2}{*}{ EWLS } & $150^{\circ} \mathrm{C}$ & $27.1 \pm 2.5$ & $71.8 \pm 2.9$ & $10.2 \pm 0.8$ & 0.75 & 72.3 \\
\hline & $195^{\circ} \mathrm{C}$ & $27.7 \pm 2.0$ & $69.9 \pm 2.5$ & $8.3 \pm 0.5$ & 0.72 & 53.0 \\
\hline
\end{tabular}

Whole lupin seeds: raw (RWLS) and extruded (EWLS); $a, b$ and $c$ are non linear parameters and Dg the in sacco degradability (see $p$ 577); $r^{2}$ is the coefficient of determination. 
(a)

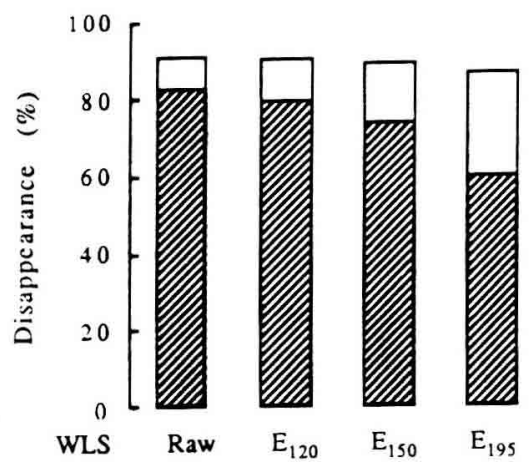

(b)

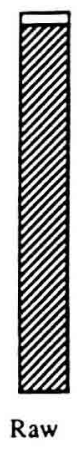

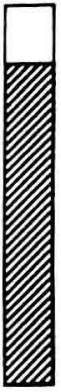
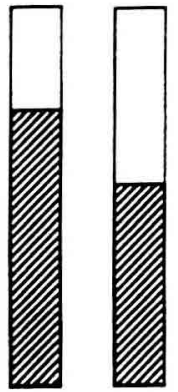

$\mathrm{E}_{120}$

$E_{150}$

$E_{195}$

Fig 2. Effect of extrusion on relative proportions of ruminal (浭) and intestinal ( $\square$ ) disappearance of dry matter (a) and nitrogen (b) from whole lupin seeds (WLS), raw and extruded at $120\left(E_{120}\right), 150\left(E_{150}\right)$ and $195^{\circ} \mathrm{C}\left(\mathrm{E}_{195}\right)$.

ly. The percent intestinal disappearances for $N$ were: 3.1 (RWLS), $15.1\left(E_{120}\right), 26.3$ $\left(E_{150}\right)$ and $44.7\left(E_{195}\right)$, the corresponding intestinal digestibilities of the rumen undegraded dietary protein were: $63.2,91.2$, 94.9 and $95.1 \%$ (these values are used for estimation of the PDI contents).

The PDIN and PDIE contents (table IV) of the RWLS were 224 and $84 \mathrm{~g} / \mathrm{kg}$ of DM respectively; heat-treatment increased these values by 10 to $32 \%$ for PDIN and by 57 to $194 \%$ for PDIE.

\section{DISCUSSION}

Though some specific characteristics of proteins, such as structure and presence of disulfide bonds influence their degradability in the rumen (Mahadevan et al, 1980), for practical purposes this degradability is often related to protein solubility in mineral buffers (Vérité and Demarquilly, 1978). Unheated WLS proteins, composed
Table IV. Evaluation of the PDI (protein digested in the small intestine) values ( $\mathrm{g} / \mathrm{kg}$ of $\mathrm{DM}$ ) of the raw and extruded whole lupin seeds.

\begin{tabular}{lrrrr}
\hline Lupin seeds & PDIA & PDIN & PDIE \\
\hline \multirow{2}{*}{ Raw } & & 13 & 224 & 84 \\
& $120^{\circ} \mathrm{C}$ & 64 & 246 & 134 \\
Extruded & $150^{\circ} \mathrm{C}$ & 111 & 264 & 173 \\
& $195^{\circ} \mathrm{C}$ & 190 & 295 & 247 \\
\hline
\end{tabular}

The PDI contents of whole lupin seeds were calculated using the equation proposed by Vérité et al (1987) and Vérité and Peyraud (1989). PDIA : PDI supplied by rumen undegraded dietary protein; PDIN : PDIA plus PDI supplied by microbial protein from rumen-degraded protein; PDIE : PDIA plus PDI supplied by microbial protein from rumen fermented organic matter.

primarily of globulins: $87.2 \%$ and albumins: $12.8 \%$ (Duranti and Cerletti, 1979) were highly soluble both in vitro $(80.5 \%)$ and probably in situ (parameter $a=80.7 \%$ ). 
This is in agreement with the results of Wohlt et al (1973) and Blethen et al (1990), who examined incidence of protein type eg, albumins, globulins, prolamins and glutelins, on $N$ solubility of various feedstuffs. The high $\mathrm{N}$ degradability in RWLS was particularly noticeable, this being associated with high initial solubility. The significant correlation between in vitro $\mathrm{N}$ solubility, coefficient $a$ and Dg. $\mathrm{N}$ values shows that it is possible to predict the degradability of $\mathrm{N}$ from the in vitro results; similarly, Aufrère et al (1988), as well as Chapoutot et al (1990) have reported a high correlation between the $\mathrm{N}$ degradability in situ of feedstuffs and that obtained with the same in vitro technique reported in this paper. Our estimates of Dg.N (95.1\%) are similar to previous reports for this oilseed, milled through a $0.8-1.0 \mathrm{~mm}$ screen (Freer and Dove, 1984; Emile et al, 1988; Demarquilly et al, 1989) whereas Valentine and Bartsch (1988) found a lower Dg.N value $(81.5 \%)$. Subjecting WLS to extrusion at 120,150 and $195^{\circ} \mathrm{C}$ reduced the solubility of proteins, thus lowering their susceptibility to ruminal degradation. This finding is in agreement with those of others on the effects of heat-treatment on both $\mathrm{N}$ solubility and $N$ degradability of various grains: soybeans, horsebeans, cottonseeds and canola (Mir et al, 1984; Michalet-Doreau et al, 1985; Deacon et al, 1988; Arieli et al, 1989; Cros et al, 1991).

Total tract $\mathrm{N}$ disappearance was extremely high for RWLS (98.2\%) as well as for EWLS (98.3\%). Consequently, extrusion at 120,150 and $195^{\circ} \mathrm{C}$ appeared to have potential for decreasing ruminal degradation without reducing intestinal digestibility of WLS proteins. It is interesting to note that the apparent intestinal digestibility values of RWLS (0.63) and EWLS (0.94) agree well with mean values of true digestibility in the small intestine of undegraded dietary protein given in the INRA tables (Demarquilly et al, 1989) for various raw oilseeds: rapeseeds, horsebeans, linseeds, RWLS (0.60) or extruded: soybeans $(0.85)$. The ruminaly bypass proteins may be least available in the intestine because much of the readily digested proteins are degraded by microorganisms, leaving only more refractory portions. These findings concur with those of Arieli et al (1989), who showed that extrusion $\left(140-160^{\circ} \mathrm{C}\right)$ of whole cottonseeds tended to elevate the apparent intestinal digestibility of N (0.76 vs 0.64 ); meanwhile, processing cottonseeds at $180^{\circ} \mathrm{C}$ diminished the intestinal digestibility $(0.22$ vs 0.64$)$. In the French protein system, the protein value of feeds and the animal requirements are both expressed in terms of true protein truly digestible in the small intestine. The results regarding PDI contents obtained for RWLS are in accordance with those of Andrieu et al (1989) for this untreated oilseed. All heat-treatments were followed by an increase in the PDI values; furthermore, the estimated PDI concentrations for EWLS are comparable to those reported for the extruded soybeans in the INRA tables (Andrieu et al, 1989).

We conclude that WLS proteins were effectively protected from ruminal breakdown by extrusion at 120,150 and $195^{\circ} \mathrm{C}$ without adverse effect on protein total degradability. The increase in the supply of dietary protein to the postruminal sections as a result of extrusion could rapidly benefit high yielding cows.

\section{REFERENCES}

Arieli A, Ben-Moshe A, Zamwel S, Tagari H (1989) In situ evaluation of the ruminal and intestinal digestibility of heat-treated whole cottonseeds. J Dairy Sci 72, 1228-1233

Andrieu J, Demarquilly C, Sauvant D (1989) Tables of feeds used in France. In: Ruminant Nutrition (Jarrige R, ed) INRA, J LibbeyEurotext, Paris-London, 213-294 
AOAC (1984) Official Methods of Analysis. Assoc Official Analytical Chemists, Washington, DC, 13th edn

Aufrère J, Michalet-Doreau B, Cartailler D (1988) Prévision de la dégradabilité in sacco de l'azote des aliments à partir de leur solubilité tampon et de leur dégradation enzymatique. Reprod Nutr Dev 28, 109-110

Blethen DB, Wohlt JE, Jasaitis DK, Evans JL (1990) Feed protein fractions: relationship to nitrogen solubility and degradability. I Dairy Sci 73, 1544-1551

de Boer G, Murphy JJ, Kennelly JJ (1987) Mobile nylon bag for estimating intestinal availability of rumen undegradable protein. J Dairy Sci 70, 977-982

Cerning-Beroard J, Filiatre A (1977) Characterisation and distribution of soluble and insoluble carbohydrates in legume seeds: horsebeans, peas, lupines. In: Protein Quality from Leguminous Crops. Commission of the European Communities, EUR 5686 EN, 65-79

Chapoutot $P$, Ternois F, Sauvant D (1990) Influence de l'azote des constituants pariétaux sur la dégradabilité in sacco de l'azote des aliments. Reprod Nutr Dev suppl 2, 149-150

Cros P, Vernay M, Moncoulon R (1991) In situ evaluation of the ruminal and intestinal degradability of extruded whole horsebeans. Reprod Nutr Dev 31, 249-257

Deacon MA, de Boer G, Kennelly JJ (1988) influence of jet-sploding and extrusion on ruminal and intestinal disappearance of canola and soybeans. J Dairy Sci 71, 745-753

Demarquilly C, Andrieu J, Michalet-Doreau B, Sauvant D (1989) Measurements of the nutritive value of feeds. In: Ruminant Nutrition (Jarrige R, ed) INRA, J Libbey Eurotext, Paris-London, 193-204

Duranti M, Cerletti P (1979) Amino acid composition of seed proteins of Lupinus albus. $J$ Agric Food Chem 27, 977-978

Emile JC, Huguet L, Hoden A, Malterre C, Micol D (1988) Sweet lupin seeds for dairy cows and young bulls feeding. In: Proc 5 th Int $L u-$ pin Conf (Twardowski Thomasz, ed), Poznan, Poland, 383-395

Freer $M$, Dove $H$ (1984) Rumen degradation of protein in sunflower meal, rapeseed meal and lupin seed placed in nylon bags. Anim Feed Sci Technol 11, 87-101

Guillaume B, Otterby DE, Linn JG, Stern MD, Johnson DC (1987) Comparison of sweet white lupin seeds with the soybean meal as a protein supplement for lactating dairy cows. $J$ Dairy Sci 70, 2339-2348

Mahadevan S, Erfle JD, Sauer FD (1980) Degradation of soluble and insoluble proteins by Bacteroides amylophilus protease and by rumen microorganisms. J Anim Sci 50, 723728

Michalet-Doreau B, Bogaert C, Bauchard D (1985) Valeur nutritive des graines de soja crues ou extrudées pour les ruminants. Bull Tech CRVZ Theix 59, 29-38

Michalet-Doreau $B$, Vérité $R$, Chapoutot $P$ (1987) Méthodologie de mesure de la dégradabilité in sacco de l'azote des aliments dans le rumen. Bull Tech CRVZ Theix 69, 57

Mir Z, McLeod GK, Buchanan-Smith JG, Grieve DG, Grovum WL (1984) Methods for protecting soybean and canola proteins from degradation in the rumen. Can J Anim Sci 64, 853865

Ørskov ER, McDonald I (1979) The estimation of protein degradability in the rumen from incubation measurements weighted according to rate of passage. J Agric Sci (Camb) 92, 499-503

Peyraud JL, Genest-Rulquin C, Vérité R (1988) Mesure de la digestion de l'azote des aliments dans l'intestin des ruminants par la technique des sachets mobiles. Reprod Nutr Dev 28, 129-130

STATITCF (1985) Logicial Statistique. Service d'Étude Statistique et Informatique de l'Institut Technique des Céréales et des Fourrages (ITCF)

Stern MD, Santos KA, Satter LD (1985) Protein degradation in rumen and amino acid absorption in small intestine of lactating dairy cattle fed heat-treated whole soybeans. J Dairy Sci 68, 45-56

Stutts JA, Nipper WA, Adkinson RW, Chandler JE, Achacoso AS (1988) Protein solubility, in vitro ammonia concentration, and in situ disappearance of extruded whole cottonseed 
and other protein sources. J Dairy Sci 71 , 3323-3333

Thomas EE, Turnbull GW, Russell RW (1987) Effect of particle size and steam treatment of feedstuffs on rate and extent of digestion (in vitro and in situ). J Anim Sci 66, 243-249

Valentine SC, Bartsch BD (1988) Degradation of dry matter, crude protein, fat, crude fibre and nitrogen free-extract in milled barley and lupin grains incubated in nylon bags in the rumen of dairy cows. J Agric Sci (Camb) 110 , 395-398

Van Soest PJ (1963) Use of detergents in the analysis of fibrous feeds. II. A rapid method for the determination of fiber and lignin. $J$ Assoc Offic Agric Chem 46, 829-835

Van Soest PJ, Wine RH (1967) Use of detergents in the analysis of fibrous feeds. IV. De- termination of plant cell wall constituents. $J$ Assoc Offic Agric Chem 50, 50-55

Vérité R, Demarquilly C (1978) Qualité des matières azotées des aliments pour ruminants. In: La Vache Laitiere. INRA Publ, Versailles, 143-158

Vérité R, Michalet-Doreau $B$, Chapoutot $P$, Peyraud JL, Poncet C (1987) Révision du système des protéines digestibles dans I'intestin (PDI). Bull Tech CRVZ Theix 70, 1934

Vérité R, Peyraud JL (1989) Protein: the PDI system. In: Ruminant Nutrition (Jarrige R, ed) INRA, J Libbey Eurotext, Paris-London, 3346

Wohlt JE, Sniffen CJ, Hoover WH (1973) Measurement of protein solubility in common feedstuffs. J Dairy Sci 56, 1052-1057 